\title{
Le Bestiaire Innu, Les Quadrupèdes. By Daniel Clément. 2012. Presses de l'Université Laval, Quebèc City. 548 pp.
}

\author{
Brien A. Meilleur ${ }^{1^{*}}$ \\ ${ }^{1}$ Laboratoire d'Eco-anthropologie et ethnobiologie, Musée de I'Homme, Paris, France. \\ *BrienMeilleur@aol.com
}

Received June 6, 2016

OPENӘACCESS

Accepted June 8, 2016

DOI 10.14237/ebl.7.1.2016.713

Copyright (c) 2016 by the author(s); licensee Society of Ethnobiology. This is an open-access article distributed under the terms of the Creative Commons Attribution-NonCommercial 4.0 International Public License (https://creativecommons.org/licenses/by-nc/4.0), which permits non-commercial use, distribution, and reproduction in any medium, provided the original author and source are credited.

Le Bestiaire Innu, les quadrupèdes is unlike most books I've reviewed, as it resembles more an ethnozoological encyclopedia than a typical academic volume and, in fact, the author describes it as such early in the work. While the publication offers a typical introduction that provides ethnographic, historical and linguistic background along with a summary of the analytical framework, and a conclusion highlighting results, the chapters themselves-20 of them-are actually lengthy, data-rich vignettes, each of which could stand alone. Collectively they present folk knowledge about quadrupedal animals drawn primarily from interviews with 12 Innu, Algonquianspeaking, hunter-gatherer/fisher-trapper communities located in the boreal forest of northeastern Canada. Each chapter-compendium provides a finely detailed description of a single species or of a small group of similar or closely related species, with meticulous depictions of their anatomy, behavior, range, habitat preference and reproductive biology, usually in this order. Each animal or species group is analyzed contextually within a corpus of Innu myths and legends and historical accounts, some dating to the $17^{\text {th }}$ century, and by comparing Innu and Western scientific knowledge. The book's format thus essentially combines what could easily be 20 independent species-by-species monographs into a massive compilation of Innu ecological knowledge and the related cosmological beliefs that are associated with these same quadrupeds. The species accounts range from that of the diminutive mouse and related species (Clethryonomys, Microsorex, Microtus, Myotis, Peromyscus, Rattus, Sorex, etc.) and squirrel (Glaucomys, Tamias, Tamiasciurus) to caribou (Rangifer tarandus) and black bear (Ursus americanus), with wolf (Canis lupus), red fox (Vulpes vulpes) and many other species in between. For more than a generation, Innu themselves, once known as Montagnais, furnished the firsthand ethnographic accounts that Clément has skillfully interwoven with Innu myths and legends, relevant published ethnohistory and Western scientific information.

Some of the analytical outcomes and conclusions of Clément's ethnozoological compendium are that extensive and highly-detailed folk knowledge exists among the Innu of the major quadruped's anatomy, behavior and classification; that this native animal knowledge permeates all aspects of Innu practical and spiritual life; that a strong correspondence exists between Innu and Western science both in the classification and the anatomical and behavioral knowledge of the animals studied, though occasional significant differences were found; that so-called 'covert categories' at higher levels of classificatory inclusion were common within the Innu zoological knowledge system; that on occasion, greater classificatory and ethological detail seemingly occurred in Innu accounts of some animals when compared to those of Western science; that along with an underlying folk classificatory structure based on observable perceptual distinctions in anatomy and behavior, Innu also employed several other classificatory schemes when describing animal and human relationships and interactions; and that Innu employed the 'theory of signatures' and 'sympathetic magic' extensively in their ontologies that account for the creation of the world and the myriad connections among animals and humans. 
Other than Clément's finely-detailed scholarship that contributes substantially to our understanding of the fast-disappearing traditional hunter-gatherer way of life, his compendium also has the potential to support Innu cultural preservation and interpretation of northern boreal forest archaeological research. It adds significantly to our continually growing appreciation of the extent and the complexity of traditional ecological knowledge among native peoples in general. 